\title{
Mari Hatavara
}

\section{Free Indirect Discourse in Early Finnish Novels by Fredrika Runeberg and Zacharias Topelius}

\begin{abstract}
[H]an såg med en namnlös känsla, den han aldrig förr erfarit, denna flicka från ett aflägset och bortglömdt land, om hvilket han knappt hade anat, att kärlek och skönhet äfven här kunde utöfva sin makt på menniskohjertat [- - ]. (HaF, 210)

He saw, with a nameless feeling that he had never before experienced, this girl from a faraway and forgotten land; he had hardly surmised that even here love and beauty could wield their power over the human heart.
\end{abstract}

In the passage above Scottish Jacob Keith, a commander in the Russian Army during the war 1741-1743 between Russia and Sweden (Finland), has met a young Finnish lady by the name of Eva Merthen for the first time. The story of the two lovers is told in the first Finnish historical novel, Hertiginnan af Finland ("The Duchess of Finland", $1850=\mathrm{HaF}$ ), alongside the events of the war and political history. The passage demonstrates a keen interest in depicting Jacob's mind, his inner feelings and thoughts as he suddenly falls in love. It uses the narrative mode of free indirect discourse (=FID), which carries traces of the discourse both of the character and the third person narrator as it depicts a character's thoughts or speech. As Brian McHale $(2005,189)$ concisely defines it, "FID is 'indirect' because it conforms in person and tense to the template of indirect discourse, but 'free' because it is not subordinated grammatically to a verb of saying or thinking." The proximity to a character's free discourse is marked by, for instance, the use of idiomatic language and deictic adverbs pointing to the character's own here and now (McHale 1978, 264-273).

McHale $(2005,189)$ has stated that "[n] othing about FID is uncontroversial". Two of the controversies revolving around FID are addressed in this article: the character and function of FID as "dual-voice discourse" and the history and distribution of the mode. Firstly, this article will survey the ways in which FID is used in early Finnish novels written by Fredrika Runeberg and Zacharias Topelius. This involves contextualising the novels' narrative practices with theoretical arguments on FID and its nature. Special attention will be paid to the question of whether FID always conveys both a character's and a narrator's voice. In the example above, the deictic markers "denna" ("this") and "här" ("here") belong to the character's discourse as they indicate his location in time and place. On the other hand, the narrator's discourse is especially clear at the beginning where Jacob's feelings are portrayed as nameless, i.e. to him they are unclear and inexpressible. An example of controversial expression is "ett aflägset och bortglömd 
land" ("a faraway and forgotten land"). This could be either the narrator's or Jacob's discourse and opinion. For instance, the mention of Jacob being the observer ("han såg", "he saw") is an extralinguistic indicator of FID in what follows (see Cohn 1978, 132-134). FID is open to various interpretations despite having some formal, identifying features (see Tammi 2006, 160). The various voices in FID and their hierarchy will be discussed in this article.

Secondly, the article will consider the history of the mode. FID is associated with figural as opposed to authorial narrative situation. The latter is considered to have reigned until the nineteenth-century, when the novel began to focus more closely on the internal lives of the characters and to employ figural narration more frequently. Jane Austen and Gustave Flaubert have often been cited as the pioneers of FID and its usage as an artistic device. ${ }^{1}$ This view is corroborated by Alan Palmer in the Routledge Encyclopaedia of Narrative Theory. In his entry on "Thought and Consciousness Representation (Literature)", Palmer $(2005,603)$ identifies a consensus on the historical development of the phenomenon: until the first decades of the nineteenth century indirect thought reports and occasional direct thought representations were the prevalent modes, and only in the course of the nineteenth century was there a change towards free indirect thought representation. Nonetheless, in Fictional Minds Palmer (2004, 244) presents Horace Walpole's The Castle of Otranto (1764) as a possible earlier example of FID. He detects some instances of the mode in the novel's representation of Isabella's mind, and ponders whether this was a new development in the narrative fiction of the period. This article investigates Finnish novels from the mid-nineteenth century, around the time of FID's assumed intense development as an artistic device. At the time FID was already in versatile use in Finnish literature, as will be demonstrated. ${ }^{2}$

The novels discussed here are Hertiginnan af Finland and Fältskärns berättelser (1853-1867=FB) by Topelius, Fru Catharina Boije och hennes döttrar (1858=FCB) and Sigrid Liljeholm $(1862=\mathrm{SL})$ by Runeberg. All of them were written in Swedish, as was most Finnish literature at the time. Topelius' literary production is broad and includes several historical novels, poetry, children's tales and so on. Besides her two historical novels, Runeberg published a collection of short stories. Topelius has an established position in the Finnish literary canon, although this is not solely due to the literary value of his works. Runeberg, on the other hand, has long been in the shadow of her husband, the Finnish national poet Johan Ludvig Runeberg. The historical nature of these novels will not be discussed in detail, though FID can surely shed light on historical representation, as it enables the author to present past minds in the discursive present (see Cohn 1978, 126-128).

All these novels feature third person narrators who do not participate in the events in the story-world, yet the relations between narrators and characters vary markedly. 
In earlier research FID was seen to distribute power from narrator to character and to function in between these two (Pascal 1977, 22, 25-16). Consequently, FID has been seen as a mode enabling a character's emancipation (see McHale 1978). This line of thought was later adopted and elaborated by feminist narratologists, who associate it with the ideological struggle between the sexes and consider FID a subversive strategy (see Lanser 1999; Mezei 1996). This will be discussed in connection with Fredrika Runeberg's novels. Recently the discussion has also evolved in the opposite direction to include the question of the narrator's control over FID (see Murphy 2007). In this respect two of the novels are of special interest: Hertiginnan af Finland and Fältskärns berättelser. In the next chapter I will discuss the narrator's controlling role in FID, then focus on how the character's voice manifests itself. At the end of the article I will return to the topic of FID as a novelty in European and Finnish literature. In conclusion the novels interpreted will be assessed according to the challenges they pose to literary history and to theoretical questions concerning FID.

\section{The Narrator's Control}

Hertiginnan af Finland is closely tied to historical writing as it comprises two parts, named "Kriget", ('The War'), and "Hertiginnan", ('The Duchess'). ${ }^{3}$ The two parts differ from each other in that the first aims at the historical depiction of national history, while the second at a more openly fictional depiction of an individual character, who nonetheless has a historical counterpart. Both parts of the novel use FID. In "Kriget" a typical instance of FID depicts collective thoughts, as in the following example:

Denna tanke uppfyllde den finska soldaten med en namnlös förbittring och sorg. Han, som utgått från bondens pörten, der stora ofredens fasor lefde friska uppå de gamlas läppar, han hade icke gått med glädje till detta krig; han visste för väl hvad landet led, och han trodde icke godt om det svenska befälet, som engång förut retirerat och oupphörligt retirerat. Men nu när kriget brutit löst, nu ville han slåss på fullt allvar, - slåss innan han öfvergaf sin fädernehydda i fiendens våld - och när han nu, efter långa månader af väntan och otålighet, fick ordres att spoliera, retirera, icke exponera, då brast hans annars oböjliga tålamod, och han utfor i förbannelser mot Lewenhaupt, Buddenbrock och allt hvad befäl hette. ( $\mathrm{HaF}, 58)$

This thought filled the Finnish soldier with a nameless bitterness and sorrow. $\mathrm{He}$, who had come from the humble huts of peasants, where the horrors of the Great Hatred were alive on the lips of the elderly, he had not gone with delight into this war; he knew too well how the country suffered, and he believed nothing good of the Swedish officers, who had retreated once and then again and again. But now that the war had broken out, now he wanted to fight in deadly earnest - fight before surrendering the humble abode of his parents to the enemy - and now that, after long months of waiting and impatience, he had received orders to destroy, to retreat, and to conceal, now his otherwise unyielding patience broke and he cursed Lewenhaupt, Buddenbrock, and all other officers. 
This passage presents a generalised example, the Finnish soldier, as the "character" whose thoughts are rendered. Technically the passage is FID: third person pronouns and past tenses are used alongside spatial and temporal adverbials referring to the "here and now", combined with language that is both idiomatic and emotive (for example, "fädernehydda", "humble abode of his parents").

The question to be asked is, whether or not a generalised example, a type, can be seen to function in the story-world as a counterpart to the narrator. In such an instance it is particularly difficult to identify a character's utterance "behind" FID, an utterance upon which our interpretation of the FID could be based. McHale $(1978,256)$ has concluded that, in fiction, the effort to derive an "original" utterance behind FID is futile and includes a fundamental misunderstanding. The indirect version provided by the text is the only version there is, and thus it is itself "original". However, it is worth pondering whether the fictional illusion of a story-world requires that we imagine an original speaker and some of the possibilities the original utterance might reasonably have followed. Here the narrator's control over FID is apparent as the original "speaker", too, is only an abstraction produced by the narrator.

In some instances the land is depicted as speaking to herself ( $\mathrm{HaF}, 48)$. In the latter part of the novel, "Hertiginnan", FID is often used to express what people did not think, as in the following example:

Det föll ingen in, att Eva Merthen ännu i denna stund var ren som dagens ljus; hon som stämt möte med officerarne, hon som utan försyn gått utöfver det skickligas gräns i sällskapslifvet, hon som haft den otroliga djerfheten att intåga i Åbo som general Keiths förklarade mätress, hvad skoning förtjenade hon, och hvad undskyllan ville man gifva dessa hemliga möten mellan den fiendtliga fältherren och en så djerf, så förlorad flicka? (HAF2, 239)

No one could have thought that Eva Merthen still, at this time, was pure as daylight; she who had arranged meetings with officers, she who had imprudently crossed the bounds of propriety in social life, she who had had the unthinkable courage to become General Keith's known mistress in the town of Turku; what mercy had she earned, and what pardon could be given for these secret meetings between the hostile warlord and such an audacious, such a lost girl?

In this passage the deictic expression "i denna stund" ("at this time") indicates a character's language, as does the emotive language used. Still, the narrator asserts that the passage describes what nobody thought. The depiction of collective thoughts, thoughts of an abstraction such as a country, and thoughts that nobody entertains, all seem to undermine the assumed tension in FID between character and narrator. Palmer (2004, 56) introduces a distinction in FID - or free indirect thought, since he discusses only the depiction of a character's thoughts, not their speech - based on whether it carries 
both the language and subjectivity of a character or only the former. Palmer suggests that only when both a character's language and subjectivity are present can a passage be regarded as an example of FID. A passage containing only a character's language, though not their subjectivity, is, according to Palmer, a coloured thought report.

Palmer's argumentation may seem an oversimplification, since most of the controversy around FID is due to the impossibility of making a distinction between subjectivity and language in fiction. FID has been under suspicion until relatively recently because it is as much an interpretative as a grammatical phenomenon (see McHale 1978, 264-273; Tammi 2006, 160-163). Still, with regard to the usage of FID in Hertiginnan af Finland, especially in the first part of the novel, Palmer's distinction between a character's language and subjectivity seems to apply, and, indeed, to clarify the situation. It is not as much a case of the narrator conveying a character's speech or thoughts but the narrator imagining how a particular group of individuals may or may not have thought or spoken. Grammatically, it is possible to identify FID, but an interpretation that would bring in a character's subjectivity seems far-stretched. Rather, the emotive language could be seen to be coloured by the narrator's attitudes.

The heroine Eva is a controversial character due to her love affair with Jacob Keith, a commander of the Russian troops. Her thoughts and feelings are often conveyed in FID. Eva's affair is condemned by her community, both due to Keith being employed by the Russians and, more importantly, due to the fact that the couple does not marry. The novel, however, defends Eva, and intends to portray her as a noble woman whose possible mistakes result from the unusual circumstances of the time. Eva suffers from the community's contempt, which eventually leads to physical isolation, and her desperate thoughts are conveyed through FID. For example: "Hvart skulle hon gå? Voro icke alla jordens portar stängda, och endast himmelens stodo öppna för den olyckliga!” (HaF, 225-226). "Where would she go? Were not all the gates on earth closed and only the gate to heaven open to the miserable?" In this passage the first question is quite certainly an example of FID, manifesting Eva's own thoughts. By contrast, the second is more disputable. It could be interpreted similarly to the first, if we conclude that the last words; "den olyckliga" are part of the narrator's discourse. This demonstrates the proximity of Eva's voice and the narrator's voice, as it seems as though the narrator uses highly emotional, rhetorically charged language to support Eva's point of view - a kind of "personalised" language, with an exclamation mark, often taken to be indicative of FID (cf. McHale 1978, 269-270). This illustrates the sympathy between Eva and the narrator.

Nevertheless, as the story of Eva contradicts the moral values even of the time in which the novel was written, FID could be interpreted as a means of indirect communication aimed at reducing the authorial narrator's responsibility - Madame Bovary has 
been interpreted in a similarly analogical manner (see Ullman 1964). This interpretation includes assuming a discrepancy between the narrator's views and Eva's views. At the time of writing the novel, it was a huge risk to defend cohabitation, even in fiction, as was demonstrated by the reception of the Swedish author C. J. L. Almqvist's novel Det går an (1839) in both Sweden and Finland. The narrator in "Hertiginnan" does, on some occasions, directly judge Eva's behaviour, and at other times supports her. Based on the instances of FID with an emphatic relation between Eva and the narrator, I posit that the duality of intention is not between Eva and the narrator, but internal to the authorial narrator, who struggles to maintain balance between vindicating Eva and gaining the audience's support. As Lennard J. Davis (1996 [1983], 132-133) has pointed out, 19th century novels often occupied this kind of double discourse where a criminal or reprehensible protagonist represented a fate both desirable and appalling. Essentially, this interpretation locates the dispute over Eva's behaviour in the narrator's discourse, not in FID or between the narrator and Eva.

Given the dominant role of the narrator, FID in Hertiginnan af Finland often comes close to Palmer's definition of the narrator's coloured thought report. Dorrit Cohn (1978, 11-14, 46-47) uses the notion of psycho-narration to designate discourse where a character's mind is rendered in the narrator's discourse. Typical of psycho-narration is the representation of preverbal thoughts, thoughts not yet put into words by the character. As Hertiginnan af Finland represents collective thoughts it is apparent that they are not verbalised by any given individual. Still, the emotionally charged and idiomatic language indicates FID as opposed to psycho-narration. With this in mind it is possible to argue that, in Hertiginnan af Finland, FID supports rather than undermines the narrator, even in instances where it seems to carry traces of a character's original utterance. Likewise, Daniel P. Gunn (2004, 40-42, 49-50) posits that Austen often uses FID to back an authorial narrator, yet to incorporate both the narrator's and a character's voice within it.

The hypothetical nature of FID is further illuminated by Anne Waldron Neumann's typology. Neumann (1986, 366-376) distinguishes three types of FID according to the probability of its containing an original utterance by a character. Instances of FID are definite, if it is possible to discern with any certainty the character's words as they were used; almost definite, if an act of speech or thought has occurred and the language of FID is typical to the character in such an instance; and, finally, indefinite, if the language used is characteristic of the character but FID may only be a report on what they would say or think. By this definition, Hertiginnan af Finland does include FID, though mostly of the indefinite type.

Fältskärns berättelser, too, typically demonstrates FID as under the extreme control of the narrator. This is especially true of the last part of the book. The novel is extensive 
and divided into five parts, each composed of three stories. The last part covers a time period in the 1770s and is mainly targeted against secularism in Enlightenment. The protagonist Paul Bertelsköld, an offspring of one of the two families depicted throughout the novel, is temporarily seduced into adopting atheist thoughts, but later returns to religion. The narrator strongly takes the side of Christian belief.

Paul's struggle with atheism is vividly depicted, and the narrator often recounts his inner monologue in direct and indirect ways. Paul is lured by thoughts of mastering the universe himself through a knowledge of chemistry.

Han insåg ganska väl, att doktor Martin hyste mycket föråldrade meningar om tingens kemiska sammansättning; nog funnos der andra grundämnen, än salt, svafvel och qvicksilfver! Det fanns ju flogiston, eldsluften, och allehanda andra märkvärdiga ämnen, som kemien just vid denna tiden framfödde. (FB5, 62)

He saw quite clearly that Doctor Martin entertained very outdated ideas of the chemical composition of things; there certainly were elements other than salt, sulfur, and quicksilver! There was, of course, phlogiston, fire air, and all sorts of other peculiar substances that were discovered by chemistry at that time.

The above passage creates ironic distance to the character as his beliefs are known to be wrong by both narrator and reader (cf. Booth 1974, 57-59) - in historical novels characters unavoidably lack the historical knowledge that readers possess. Neither of the sentences is completely in FID but both are partially: the first shifts from the narrator's discourse to FID, the second from FID back to the narrator's discourse. FID is used as a vehicle for irony, for which it is generally suitable (see McHale 1978, 275). Yet, the narrator's own discourse further ironises Paul's thoughts by pointing out explicitly how outdated and foolish his beliefs are.

In Fältskärns berättelser FID is often used to convey irony towards a character whose opinions differ from those of the narrator. The narrator's discourse surrounds FID, thus guaranteeing that the irony is understood. Stephen Ullman (1964, 107-109) has discussed a similar use of FID in Madame Bovary and concluded that FID is used to portray and parody characters. FID is suitable for this as it contains expressive elements that can be exaggerated into a caricature - as, in Paul's case, his disbelief in God and adjacent belief in science, which the narrator sees as a fallacy. Terence Patrick Murphy (2007, 28, 35 and passim) has given special attention to the degree to which FID might resemble the free discourse it is possible to detect in a character's speech. Murphy calls the narrator's rhetorical means and idiomatic vocabulary used in reporting a character's utterance "monitored speech". Monitored speech emphasises the narrator's role as the filter through which a character's assumed words are processed. Cohn (1978, 119-120) states that ironic FID can resemble mock imitation: the narrator temporarily takes the position of a character and imitates his style. In Fältskärns berättelser the narrator's 
discourse usually frames and contextualises Paul's FID, as in the passage quoted above. Here, and in other places as well, the narrator's own discourse makes sure that readers see the ridiculous nature of Paul's ideas.

Ullman $(1964,112-113)$ claims that Flaubert occasionally uses FID as a façade in which both style and vocabulary are tightly dictated by authorial intention. Thus the narrator's voice dominates the discourse and the character's voice is hard to discern. Fältskärns berättelser follows this practice, but the narrator's control is prevalent even in passages textually marked as belonging to Paul; these passages often include vocabulary that seems to belong to the narrator. This is particularly evident as Paul often uses biblical vocabulary and imagery when proclaiming his atheism. For example, he refers to Dr Martin Weis, an alchemist who shows him the art of making gold, as a serpent who has lured him with the tree of knowledge: "Det var dock ni, som först lät mig blicka in i de vetenskapliga hemligheternas afgrund och frestade mig, som ormen i paradiset, med kunskapens träd" (FB5, 16). "It was you who first let me glance into the abyss of scientific secrets and, like the serpent in paradise, tempted me with the fruit of the tree of knowledge." So it seems that in Fältskärns berättelser the narrator's voice not only controls FID but also those passages technically within a character's free discourse. This view is based on the ideological interpretation of vocabulary, and comes close to an interpretative practice common with FID, where it is identified contextually or ideologically, based only on the values expressed (cf. McHale 1978, 272-273; Tammi $2006,160-161)$. This means that the ideological opinions of a character gain ground in what is technically the narrator's discourse; this can be seen in a character's choices of words. Fältskärns berättelser turns the situation upside down: it is the narrator who penetrates a character's discourse, not vice versa. Besides Paul, several other characters in the novel employ biblical language and direct, often lengthy quotations from the Bible. For example, Paul's cousin reads aloud two passages from the Bible, both directly quoted in the text and a whole page in length. This happens after Paul has expressed his lack of faith. The extracts are chosen well: Isaiah 28th, a warning for blasphemers, and a Psalter, where God is praised over humanity. Thus Paul's rebellion is opposed with great authority.

The different fictional levels and ideologies in Fältskärns berättelser can be approached using Mihail Bakhtin's theories on polyphony; Bakhtin places great emphasis on the content, not the formal features, of an utterance. According to Bakhtin (1984 [1963], 188-190, 193-194) any utterance is dialogical in nature; in particular, he regards parody and stylisation as always referring both to the object of the utterance and to foreign speech. Bakhtin (1984, 186-187) claims that the direct speech of characters is objectified discourse, because it not only refers to its own object but also carries authorial meaning. Using Bakhtin's theories it is possible to conclude that in Fältskärns 
berättelser biblical vocabulary acts as a kind of foreign element in the protagonist's discourse. It contradicts his other words and actions. However, Paul undergoes a dramatic change in behaviour after the first of the three stories forming the novel's fifth part. Paul hears that his mother has gone missing and concentrates his energy on finding her. At the same time his defiant attitude disappears, and he gradually becomes more and more religious. So it seems that the polyphony, after all, is not based on tension between the respective ideologies of Paul and the narrator, but rather it is founded on the discrepancies within Paul's own ideology. The foreign element turns out to be the anti-religious, scientific thoughts of the Enlightenment. It is present in Paul's speech for a while, but subsequently disappears.

The foreign element, the atheist thoughts supported by neither the narrator nor the implied author, is estranged in the novel in several ways. Only Paul expresses these thoughts. When he does so in free discourse, his utterances still carry the strong hallmarks of religious vocabulary and imagery (as in the passage from page 16 in the novel). In FID the narrator's voice ironises Paul's words both within FID and in the surrounding sentences (illustrated by the extract from page 62). Religious and biblical language is used and preferred by the narrator and supported by the implied author. Paul's attempts to oppose the religious ethos in his speech and through FID are subverted by the dominance of one idiom. The narrator holds authority, and Paul's voice is adjusted to convey the same ideology as he converts back to Christianity. After the conversion his fate is questioned by a woman to whom he is attracted - albeit a woman who is depicted as somewhat light-minded.

Nu blef det honom plötsligt klart, att han hade framför sig en afgrund af förfärande tomhet. Hvad skulle han svara? Tidsandans mörka tvifvel satt der framför honom i den skönaste hamn, väpnad med hela behagets tjusning, med hela den första kärlekens förförande trollmakt och framkastade lätt, i förbigående, en fråga på lif och död, om tid och evighet. (FB5, 401)

Now suddenly it became clear to him that an abyss of frightful emptiness lay before him. What should he say? Zeitgeist's gloomy doubt sat there in front of him in the most beautiful of havens, armed with the entire enchantment of pleasure, with the whole frightful bewitchment of first love, and presented lightly, in passing, a question of life and death, of time and eternity.

This extract indicates FID after the first sentence: question form and verb form (conditional mood), deictic marker "der framför honom" ("there in front of him"). Yet it is coloured by the opinions the narrator has held from the start: Paul's antireligious thoughts express the spirit of the time, not his own thinking, and the question of belief is a question of salvation. Thus Paul has been subordinated to the religious discourse. After the extract quoted above, he emphatically declares his faith. 
In summary, Hertiginnan af Finland and Fältskärns berättelser use FID with strong, authorial narrators. The narrators are able to control FID for themselves; to imagine a collective voice as an "original" utterance or to ironise and finally dispel those elements opposing the narrator's view. The case is quite different in Sigrid Liljeholm and Fru Catharina Boije.

\section{Emancipating Characters}

Sigrid Liljeholm depicts wartime Finland at the turn of the 17th century. The protagonist Sigrid is a young girl carried away by dramatic events: her home is attacked, she resides in a castle under siege, and she manages to help her father escape from prison. The novel contains lots of dialogue. The narrator is mostly covert and focalisation varies a great deal.

Sigrid is first observed by the narrator or from her mother's perspective. Her mother Metta is very dominating and regards Sigrid as too shy and inefficient: "Ja, ungdom och visdom! säger man, och så säfligen hon är, icke har man mycken nytta af henne [- -]” (SL, 16-17). "Oh, yes, youth and wisdom! they say, and so bashful is she, not of much use [- - ." The narrator repeatedly characterises Sigrid as timid. On one occasion her home has been attacked by rebelling peasants, but she has been led to safety by a young knight Enevald Ficke. After the attack she summons up the courage to thank him.

Sigrid hade, blyg och förlägen, satt sig i ett horn af rummet, men fattade dock slutligen mod, och steg fram till Enevald. "Tillåt mig", sade hon djupt rodnande, "att tacka er [- - ]." [- - Fru Metta förundrade sig öfver att Sigrid hade vågat tilltala den främmande herrn, men sedan hon sjelf förenat sina tackar med hennes, tillade hon [- -.$(S L, 58)$

Sigrid, timid and awkward, had seated herself in a corner of the room, but she eventually mustered courage and stepped forward to Enevald. "Please allow me," she said, blushing deeply, "to thank you [- - ]" [- - Metta, the lady of the house, wondered how Sigrid had dared to speak to the strange gentleman, but after joining her thanks, she added [- - ].

The narrator points to Sigrid's shyness, which is then further illuminated in Metta's thoughts. With regard to the representation of consciousness, the words "främmande herrn" ("the strange gentleman") are interesting. They are presumably part of Metta's thoughts, which the narrator quotes in FID. Yet, Enevald is not a "strange gentleman" to Metta, who has recently spoken with him treating him as an equal. Thus the utterance represents what Metta thinks Sigrid thinks, and is conveyed by the narrator in FID. Sigrid's mind is estranged behind two other discourses: the mother's and the narrator's.

Only later in the novel do Sigrid's point of view and her own voice come to prominence. A turning point in Sigrid's life and in the narrative is when Sigrid decides to try 
to rescue her father who is imprisoned in Turku castle.

Tusende tankar svärmade i Sigrids hufvud. [- - ] Vore det möjligt att Sigrid skulle kunna göra något för sin far? Hon hade så ofta blifvit beskylld för att vara för mycket stillsam, för mycket rädd att framträda; var hennes tvekan nu endast en sådan yttring af hennes allt för tillbakadragna sinne? Och hon viste dock med sig sjelf, att hon icke skulle ryggat tillbaka, om hon med sitt lif kunnat återköpa sin fader. (SL, 263)

Thousands of thoughts swarmed in Sigrid's head [- - Was it possible that Sigrid could do something for her father? She had so often been blamed for being much too quiet, much too afraid to stand out; was her doubt now only an expression of her excessive reserve? After all, she knew that if she could save her father with her life, she would not recoil.

In this passage Sigrid herself ponders her shyness, and her voice becomes part of the text in FID. According to Cohn $(1978,116)$ novels that utilise FID often begin from a neutral and objective narration and only then proceed in rendering the characters' minds. Sigrid Liljeholm is focalised from the start, but Sigrid's consciousness is approached gradually. This emphasises her importance in the novel. ${ }^{4}$ The above passage also shows how Sigrid is ultimately very brave and willing to take risks. This impression of Sigrid, first put forward in her own words quoted above, is later confirmed by both Metta and the narrator (see SL, 327). From this point on, Sigrid's voice is heard both in her free discourse and in FID.

This stands in contrast to Fältskärns berättelser, in which Paul expresses himself in FID right from the beginning. Later, as he abandons his atheistic views, FID is less frequent. Due to FID's tendency to give a close depiction of the characters' psychology in fiction, the mode has been associated with portraying a character's inner crisis (see Cohn 1978, 112-113; Nelles 2006, 128). This idea suits both Paul and Sigrid. Paul's crisis is the starting point of the fifth part of Fältskärns berättelser, as the intention is to strive against atheism in Enlightenment. His crisis is quickly resolved, and this enables the narrator to carry on in the religious ethos. The crisis is not as much personal to Paul, rather it serves the authorial intentions of exemplifying the inferiority of atheism.

Sigrid, on the other hand, is led into a crisis in the second half of Sigrid Liljeholm. Her crisis is personal, and stems from the contradictory demands of her position as a girl of nobility on the one hand and those of the situation and her will to act on the other hand. This culminates in her relationship with Enevald, who in the course of events first becomes engaged to Sigrid but later abandons her, using her alleged unladylike behaviour as an excuse. As a result, Sigrid chooses to live independently, free from male dominance. In order to achieve this, she goes through an inner crisis. Different narrative modes are used when she learns that Enevald has a new loved one. 
Det stormade i Sigrids vanligen så fridfulla hjerta. Enevald hade försmått henne, han hade gjort henne till ett mål för hån och spe, eller ett föraktfullt medlidande. Han hade bedragit hennes kärlek, tillintetgjort hennes framtid, och dock - icke ville hon vålla honom sorg! - "Vara ett hinder för hans förening med den han älskade? Nej, nej!” (SL, 351)

In Sigrid's heart, usually so serene, it was storming. Enevald had spurned her; he had made her a target of scorn and ridicule, of condescending compassion. He had betrayed her love, destroyed her future - yet still she could not bear to cause him sorrow! - "To be a hindrance to his union with the one he loves? No, no!”

This passage shifts from the narrator's discourse to FID and quoted monologue. FID in the second and third sentences is marked not only grammatically by the personal pronouns but also by their emotional content and the use of the exclamation mark, which is repeated in free discourse. This flexibility in narrative modes is typical of Sigrid Liljeholm and exemplifies the novel's emphasis on Sigrid's feelings and the narrator's aptitude for allowing the characters to take over.

Nonetheless, the novel also contains passages in which the narrator assumes a strong, authorial voice. This happens with regard to a historical character Klaus Fleming, who embodies the patriarchal forces that oppose Sigrid. Fleming is strongly supported by the narrator who repeatedly praises his heroism. This is especially true after Fleming's death:

Den store, den mäktige anden hade fallit, han, som brutit sin väg rakt som viggen genom trädet, orörd af smicker, löften och hotelser, orörd af tadel och hån, blott lydande hvad han ansåg för rätt. Eller såsom en af hans fiender om honom klandrande uttryckte sig: "Herr Klas var en enfaldig man, som ej förstod sig på annat, än att gå raka vägen fram”, ett tadel, jemngodt med det skönaste beröm. (SL, 159)

The great, the mighty spirit had fallen; he, who had broken his way straight through like a bolt of a lightning through a tree; untouched by flattery, promises, and threats; untouched by rebuke and mockery; obeying only that which he saw as right. As one of his enemies said in his reproach, "Mr. Klas was a simple man who knew only how to go straight ahead," a reproof as great as the most eloquent praise.

The narrator openly admires Fleming here and a little later even states that the coming generations will show more appreciation to his greatness (SL, 160). In addition, Fleming is allowed to speak for himself right from the start. When he is first introduced he discusses the allegations his opponents have made against him. The other discussant is his wife Ebba Stenbock, and the tone is very loving and supporting. (See SL, 33-39.)

The narrator's attitude and conduct towards Fleming is quite the opposite from that towards Sigrid. Fleming is clearly and openly supported by the narrator's comments, 
in free quotations on his own and in the words of the other characters. Contrastingly Sigrid is first observed from a distance and only later given a voice of her own. Furthermore, the narrator places Sigrid and Fleming in entirely different worlds, for example by commenting on Fleming's visit to Sigrid's home, where he discusses the war with Sigrid's father. Here Fleming serves as a generalised example of men, as the same modifiers ("stor", "mäktig"; "great", "mighty") are used as in the last quotation, where they are used to designate his qualities.

De storas, de mäktigas strider, hvad röra de väl en ringa landtflickas öde? Må hon sitta vid sin spinnrock, må hon sköta sin kök, sinä blommor, sin grannlåt och se till blott att hemmet är dammfritt, och lemna åt männen, de som makt och kraft hafva, att deltaga i lifvets stora skiften! (SL, 177)

The great, the mighty, and their feuds; what have they to do with the fate of a trifling peasant girl? Let her sit by her spinning wheel; let her look after her kitchen, her flowers, her fripperies, and see that the home is free from dust, and leave it to the men, those who have power and strength, to take part in life's great changes!

The gap between the sexes is further illuminated by the way in which the men, including her fiancé, treat Sigrid and other women. Women are often put in their place, and overstepping the boundaries is punished; Enevald abandoning Sigrid serves as an illustration. According to Eneveld, Sigrid lost her grace and potential for marriage when she interfered in manly matters by rescuing her father (SL, 370-372).

The important question here concerns the narrator's sex and consequently, which side the narrator is on. A heterodiegetic narrator does not have a personality and thus is not necessarily a he or a she. On the other hand, Sigrid Liljeholm contains a frame story with a female character as the compiler of the upcoming story. Moreover, some theorists claim that the author's sex determines a heterodiegetic narrator's sex. The issue is further developed by Susan S. Lanser (1999, 168-170 and passim.), who uses sex to designate the identification of textual characters to either male or female, and gender to refer to the textual practices that through cultural codes implicate sex.

Lanser, who has formerly $(1981,167)$ argued for the decisive role of the author's sex in the case of a heterodiegetic narrator, has later (1999, 176-177) concluded that those narrators may not have sexual specificity. She uses Northanger Abbey to demonstrate how a narrator may never designate their sex. Still, some theorists have claimed that Northanger Abbey features a female narrator, because the novel's narrator prefers novels written by women. Continuing this line of thought, one could conclude that the narrator in Sigrid Liljeholm is male because of the praise (s)he lavishes on Klaus Fleming as a masculine hero. Kathy Mezei's $(1996,67,70)$ view on FID as a mode enabling both discursive and ideological interplay between a narrator and a character provides a suit- 
able angle here. Mezei sees FID as a site of conflict, a battleground for power not only between a narrator and a character, but also between different positions of dominance. In particular, she sees the mode as enabling female voices to emerge through a character's discursive presence. The assumption that the narrator in Sigrid Liljeholm is male would lead to an interpretation whereby Sigrid as a female character, who struggles with her femininity, opposes the narrator's dominant position in the instances where FID carries her discourse.

This kind of interpretation would, however, require a distance between the voices of Sigrid and the narrator in FID, preferably an ironic one. Despite this, there is no distance, as the above example from page 351 demonstrates; Sigrid's voice is approached emphatically without ideological distancing. The narrator seems to carry a controversial agenda: (s)he both praises masculine heroism and allows a female, emancipatory character to appear in FID with emphatic implications. Additionally, the narrator's remark on women's role carries traces of ironic exaggeration. I argue that the narrator uses both male and female voices and intentionally plays them against each other. Diana Wallace (2005, 16-18, 23), who has studied British historical novels written by women, posits that female history writing has suffered from women's oppressed and silenced position in society. That is why women writers have found and utilised the opportunity offered by historical material: it enables them to adopt and utilise a male voice as a kind of a mask. Through a male protagonist or a narrator in a historical-political setting, a female writer is able to assume a performative masculine role. This happens in Sigrid Liljeholm when the narrator, in a very forward manner, extols Fleming as a hero.

In Sigrid Liljeholm the narrator plays with both feminine and masculine roles, but is notably more straightforward in the masculine role. Femininity in the novel is most prominently expressed through Sigrid's character, particularly in passages of FID. Like other indirect modes in Sigrid Liljeholm, such as mise en abyme, FID allows a character's point of view to come forward. As Mezei $(1996,71-72)$ has put it, FID is a means to convey the "other story", the story of those marginalised. The narrator refrains from praising Sigrid openly, but expresses sympathy by allowing her voice to be heard in FID.

Although less used in Fru Catharina Boije, FID functions in a similar fashion in this novel too. The mode is mostly used in connection with Cecilia, the younger daughter, who struggles to come to terms with her love for a devious man named Carl.

Hon ägde ju allt, hvad hennes hjerta kunde önska, hon hade ju ej ens i sina drömmar kunnat tänka sig Carl behagligare och älskvärdare än han var; och dock, hvarföre var det stundom som om hon skyggat tillbaka för att undgå att vidröra is, vid uttryck, som undföllo honom. (FCB, 188)

She had everything her heart could desire, not even in her dreams could she have imagined Carl to be more delightful and charming than he was; and yet, 
why was it sometimes that she drew back as though to avoid touching ice, frightened by something that Carl had let slip.

The passage above is FID on Cecilia's thoughts as she ponders her situation. In Fru Catharina Boije the narrator is covert and makes no value statements. Thus there is no such discrepancy between the narrator and the character as in Sigrid Liljeholm. The instances of FID in Fru Catharina Boije are emphatic towards Cecilia's way of thinking, but disillusioned she finally dies of sorrow and shock. In Sigrid Liljeholm the heroine confronts more textual opposition but is ultimately more successful in emancipating herself both as a voice and a subject, as the narrator covertly takes her side.

\section{FID as a Novelty?}

FID is associated with a change in literary repertoire as narrative modes became more modern around the middle of the 19th century - particularly in the case of Flaubert (see Bal 1997 [1985], 45; Cohn 1978, 25, 122; Stanzel 1984 [1979], 4-5, 187). It is a question of transition from authorial to figural narratives, from strong, personalised narrator to the minute depiction of characters' minds. Ullmann (1964, 118-119) associates Flaubert's use of FID with the intention of diminishing authorial presence. For the same reason he and many others see the interpretative scope in which a character gains prominence to have contributed to Flaubert's eventual prosecution (cf. LaCapra 1982, Teilman 2000).

Other arguments nonetheless exist. Particularly in the case of Jane Austen, many claim that the common beliefs of FID are inappropriate. Gunn $(2004,35)$ argues for two interpretative fallacies with regard to the FID commonly found in Austen studies. Firstly, the mode is interpreted to carry meanings from a character's utterance and to cause a narrator to stand aside. Secondly, FID is perceived to be unbalanced and disturbing to the reading process, since it lessens a narrator's authority and enables a character's contesting voice to come forward. As Gunn sees it, these features do not hold true in Austen's work. He argues that Austen uses the mode with a reliable, authorial narrator.

Gunn (2004, 35-36) emphasises the narrator's role in Emma; as a result FID is interpreted to be an imitation or adaptation by the narrator, and not as the manifestation of a character's utterance. Roy Pascal $(1977,29-31)$ in his early study emphasised the presence of both, the imitator and the imitated, in FID. Pascal is reluctant to tie the mode to any specific functions, and it does seem more productive to see it as enabling a variety of different narrative and stylistic implications, both in figurative and authorial mode. Pekka Tammi (2006, 160-162) has indicated that the trend in post-classical narratology is to pay attention to the means of depicting the minds of the characters, which undermines the importance of narrators. Still, FID cannot and should not be 
confined to these categories. Topelius' novels in particular demonstrate the possibility of FID to be present in authorial narrative, while also supporting the narrator's view. Sigrid Liljeholm, on the other hand, presents a narrator who both opposes and supports a character represented through FID by herself adopting multiple roles.

The history of FID in Finnish literature has been discussed by Maila Valkeakari, who has studied the emergence of FID in Finnish literature in her article "Eläytymisesityksen tulo suomalaiseen kirjallisuuteen" (1969). She also summarises the mode's development in other European countries, with results similar to those presented above. She emphasises the shift during the latter half of the 19th century, and the importance of Austin and Flaubert (Valkeakari 1969, 136-137). With regard to Scandinavian literature Valkeakari (1969, 137-148) summarises that FID was used by Norwegian realists during the 1870s, and became more widespread among Norwegian and Swedish authors during the 1880s and 90s. In Finnish literature (written in Finnish) Valkeakari names Juhani Aho as the first to introduce the mode during the 1880s and 1890s, and Arvid Järnefelt from the 1890s. The same line of thought is followed by Leevi Valkama in his essays from 1960 and 1970 (see Valkama 1983, 20-27, 202-217). Valkama stresses the importance of Aho and his manifold use of the mode. The first Finnish study with detailed formal argumentation is Tammi's Kertova teksti (1992). Tammi does not, however, discuss the history of FID but concentrates on analysing its use in Marja-Liisa Vartio's modernist prose from the 1950s and 60s. ${ }^{5}$

These novels by Runeberg and Topelius both exemplify and bring into question many of the theoretical assumptions of FID. They use FID in various ways, each with its own effect on interpretation. In some cases FID is strongly contextualised by a narrator, at other times it is not; some occurrences indicate sympathy, others irony between a narrator and a character. Moreover, FID can include two voices, or belong to one agent (mockingly) imitating the other. In some novels, like Sigrid Liljeholm, FID is used in order to enable different voices to emerge and to make interpretations contradicting the narrator's view. In others, like Fältskärns berättelser, it is used in an environment that denies real polyphony.

These two novelists each had a distinctive way of adopting the conventions and demands of the literary system of their age. The aesthetics of the time of writing included an aspiration towards depicting reality and the characters' psyche. Technically, critics favoured "showing" as opposed to "telling", as objectivity was a desirable impression. Yet, at the same time, the function of literature was to teach a clear moral lesson. Topelius' novels, with their strong authorial narrative voice, responded to the demand for writing Finland a history of its own, and conveying a moral world view. Runeberg's novels, with the implicit strategies they used, often resulting in a controversial view of history, were not always understood by contemporary critics. 
The novels by Runeberg and Topelius prove to be surprisingly modern as regards narrative techniques. Runeberg's novels in particular contain several reflexive levels, which produce interpretative metalevels. In the light of the functions of FID, the novels indicate the mode to be inclined to appear with ideologically charged material. Still, the mode is not only suitable for contrasting a character's view to that of a narrator or for enabling emancipative results. The role of the narrator is important and may take diverse forms. The duality of voices inherent in FID offers interpretative challenges which should not be invalidated by strict taxonomy. Neither should interest in studying the history of the mode be confined to the latter half of the 19th century and thereafter.

\section{Quotes from Runeberg and Topelius translated by Timo Lubtanen.}

\section{Notes}

${ }^{1}$ For the distinction between figural / authorial narrative situation and its historical development with regard to FID, see Dorrit Cohn (1978, 25-26, 122, 138-140), Franz K. Stanzel (1984 [1979], 4-5) and Mieke Bal (1981, 45). On the role of Austen and Flaubert in the development of FID see Stephen Ullmann (1964, 95, 98-100), Roy Pascal (1977, 10-11), Dominick LaCapra (1982), Stina Teilmann (2000) and Daniel P. Gunn (2004).

${ }^{2}$ This issue, in connection to historical novels, is discussed in my Historia ja poetiikka Fredrika Runebergin ja Zacharias Topeliuksen historiallisissa romaaneissa (Hatavara 2007).

${ }^{3}$ I have further illuminated the nature of the two parts and their relation to history in Hatavara 2004.

${ }^{4}$ For more about Sigrid and her role in the novel, see my argumentation in Hatavara 2006, 155-156 and passim.

${ }^{5}$ Tammi has continued with theoretical interest on FID in, for example, Tammi 2006.

\section{Bibliography}

\section{Primary Sources}

$\mathrm{HaF}=$ Hertiginnan af Finland. Romantiserad berättelse, jemte en historisk skildring af Finska Kriget åren 1741-1743. Z. [acharias] Topelius. Helsinki: A.W. Gröndahl 1850. FB = Fältskärns berättelser. Z. [acharias] Topelius. Stockholm: Albert Bonniers förlag. 1877-1873 [1853-1867] (Första Cykeln 1877 [1853], Andra Cykeln 1874 [1856], Tredje Cykeln 1874 [1858], Fjerde Cykeln 1873 [1864], Femte Cykeln 1873 [1867]. $\mathrm{FCB}=$ Fru Catharina Boije och hennes döttrar. En berättelse frän stora ofredens tid. Af -a -g [Fredrika Runeberg]. Helsinki: Finska Litteratur-sällskapet 1858.

$\mathrm{SL}=$ Sigrid Liljeholm. Roman af -a -g [Fredrika Runeberg]. Helsinki: Theodor Sederholms förlag 1862. 


\section{Secondary Sources}

Bakhtin i984 / 1963: Problems of Dostojevsky's Poetics. Problemy poetiki Dostoevskogo. Ed. and transl. by Caryl Emerson. Manchester: Manchester University Press. BaL, MIeKe I997 /I985: Narratology. An Introduction to the Theory of Narrative. Toronto: University of Toronto Press.

BoOTH, WaYne C. I974: A Rhetoric of Irony. Chicago: University of Chicago Press. COHN, DORRIT I978: Transparent minds. Narrative Modes for Presenting Consciousness in Fiction. Princeton: Princeton University Press.

Davis, Lennard J. I996 / I983: Factual Fictions. The Origins of the English Novel. Philadelphia: University of Pennsylvania Press.

GunN, DANIEL P. 2004: Free Indirect Discourse and Narrative Authority in Emma. In Narrative 1: 2004, 35-54.

hataVARA, Mari 2004: History and Her Story. The First Finnish Historical Novel between Romantic Imagination and Historicist Determination. In Intertextuality and Intersemiosis. Ed. by Marina Grishakova and Markku Lehtimäki. Tartu: Tartu University Press, 265-286.

HATAVARA, MARI 2006: Fredrika Runeberg's Strategies in Writing the History of Finnish Women in Sigrid Liljeholm. In Scandinavian Studies 2: 2006, 153-166.

HataVARA, MARI 2007: Historia ja poetiikka Fredrika Runebergin ja Zacharias Topeliuksen historiallisissa romaaneissa. Helsinki: SKS.

LACAPRA, DOMINICK I982: Madame Bovary on Trial. Ithaca: Cornell University Press. LANSER, SUSAN SNIADER I 992 Fictions of Authority. Women Writers and Narrative Voice. Ithaca: Cornell University Press.

LANSER, SUSAN SNIADER I 999: Sexing Narratology: Towars a Gendered Poetics of Narrative Voice. In Grenzüberschreitungen: Narratologia im Kontext. Transcending Boundaries: Narratology in Context. Ed. by Walter Grünzweing and Andreas Solbach. Tübingen: Gunter Narr Verlag, 167-183.

MCHALE, BRIAN I978: Free Indirect Discourse: A Survey of Recent Accounts. In Poetics and Theory of Literature 3: 1978, 249-287.

MCHALE. BRIAN 2005: Free Indirect Discourse. In Routledge Encyclopedia of Narrative Theory. Ed. by David Herman, Manfred Jahn and Marie-Laure Ryan. London and New York: Routledge, 188-189.

MEZEI, KATHY I996: Who is speaking here? Free Indirect Discourse, Gender, and Authority in Emma, Howards End, and Mrs. Dalloway. In Ambiguous Discourse. Feminist Narratology \& British Women Writers. Ed. by Kathy Mezei. Chapel Hill: The University of North Carolina Press, 66-92.

MURPHY, TERENCE PATRICK 2007: Monitored Speech: The 'Equivalence' Relation between Direct and Indirect Speech in Jane Austen and James Joyce. In Narrative 1: 2007, 
$24-39$

NELLES, WILliam 2006: Omniscience for Atheists: Or, Jane Austen's Infallible Narrator. In Narrative 2: 2006, 118-131.

neumann, anne Waldron 1986: Characterization and Comment in Pride and Prejudice: Free Indirect Discourse and "Double Voiced" Verbs in Speaking, Thinking and Feeling. In Style 3: 1986, 364-394.

PALMER, ALAN 2004: Fictional Minds. Lincoln and London: University of Nebraska Press.

Palmer, alan 2005: Thought and Consciousness Representation (Literature). In Routledge Encyclopedia of Narrative Theory. Ed. by David Herman, Manfred Jahn and Marie-Laure Ryan. London and New York: Routledge, 602-607.

PASCAL, ROY 1977: The Dual Voice. Free indirect speech and its functioning in the nineteenth-century European novel. Mancester/Totowa, New Jersey: Mancester University Press/Rowman and Littlefield.

STANZEL, FRANZ K. I984 / I979: A Theory of Narrative. Transl. by Charlotte Goedsche. Cambridge: Cambridge University Press.

TAMMI, PEKKA 1992: Kertova teksti. Esseitä narratologiasta. Helsinki: Gaudeamus.

TAMMI, PEKKA 2006: Exploring terra incognita. In FREE language INDIRECT translation DISCOURSE narratology. Linguistic, Translatological and Literary-Theoretical Encounters. Ed. by Pekka Tammi and Hannu Tommola. Tampere Studies in Language, Translation and Culture A 2. Tampere: Tampere University Press, 159-173.

teILMAnN, stina 2000: Flaubert's Crime: Trying Free Indirect Discourse. In Literary Research/Recherche littéraire Spring-Summer 2000, 74-87. ullmann, stephen i964: Style in the French Novel. Oxford: Basil Blackwell. valkama, Leevi 1983: Proosan taide. Viisi tutkielmaa. Porvoo, Helsinki, Juva: WSOY. VALKEAKARI, MAILA 1969: Eläytymisesityksen tulo suomalaiseen kirjallisuuteen. In Sananjalka 11, 136-148.

wallace, Diana 2005: The Woman's Historical Novel. British Women Writers, 19002000. Basingstoke: Palgrave Macmillan. 